\title{
Wykorzystanie źródeł i narzędzi elektronicznych przez polskich studentów kierunków humanistycznych ${ }^{1}$
}

\author{
Anna Kamińska \\ Instytut Informacji Naukowej i Studiów Bibliologicznych \\ Uniwersytet Warszawski
}

\begin{abstract}
Abstrakt
Cel/teza: Celem artykułu jest charakterystyka zachowań informacyjnych związanych z wykorzystywaniem przez studentów kierunków humanistycznych naukowych źródeł i narzędzi elektronicznych do przygotowania prac magisterskich. Podstawę charakterystyki stanowią wyniki badań przeprowadzonych wśród studentów Uniwersytetu Warszawskiego.

Koncepcja/metody badań: W badaniach, przeprowadzonych od marca do maja 2014 r. wykorzystano podejście jakościowe, stosując technikę wywiadu częściowo ustrukturyzowanego. Treść wywiadów po ich przeprowadzeniu transkrybowano i opracowano za pomocą programu do analizy danych jakościowych Welf QDA. Do analizy zebranego materiału wykorzystano technikę kodowania znaczenia. Próbę badawczą stanowiła grupa 14 studentów drugiego roku studiów magisterskich: 7 magistrantów polonistyki i 7 magistrantów historii.

Wyniki i wnioski: Analiza danych zgromadzonych na podstawie wywiadów pokazała, że respondenci używali źródeł elektronicznych w momencie, gdy dostęp do materiałów w formie tradycyjnej był utrudniony, zaś elektroniczne narzędzia wykorzystywali do wyszukiwania konkretnych publikacji w wersji papierowej lub elektronicznej. Najpopularniejszymi okazały się biblioteki cyfrowe, wyszukiwarka internetowa Google oraz elektroniczne katalogi bibliotek. Stwierdzono niewielką znajomość wśród studentów takich narzędzi, jak menedżery bibliograficzne i rzadkie z nich korzystanie przy pisaniu prac magisterskich. Mimo ogólnej otwartości studentów na technologie cyfrowe i popieranie przez nich rozwoju naukowych zasobów Open Access, potwierdzone zostało ogólne przekonanie o przywiązaniu humanistów do pracy w środowisku papierowym.

Oryginalność/wartość poznawcza: Przeprowadzone badanie uzupełnia lukę w zakresie badań nad zachowaniami informacyjnymi magistrantów. Jego szczególną wartość stanowi wybór grupy badawczej spośród studentów kierunków humanistycznych, którzy do tej pory bardzo rzadko byli obejmowani tego typu badaniami.
\end{abstract}

\section{Słowa kluczowe}

Cyfrowa humanistyka. Cyfrowe zasoby naukowe. Edukacja informacyjna. Elektroniczne źródła naukowe Elektroniczne narzędzia naukowe. Kompetencje informacyjne. Studenci humanistyki. Zachowanie informacyjne.

Otrzymany: 28.08.2014. Poprawiony: 25.09.2014. Zaakceptowany: 09.10.2014.

${ }^{1}$ Artykuł powstał na podstawie pracy magisterskiej o tym samym tytule, napisanej pod kierunkiem prof. dr hab. Barbary Sosińskiej-Kalaty, obronionej w lipcu 2014 r. na kierunku Informacja Naukowa i Bibliotekoznawstwo na Uniwersytecie Warszawskim. 


\section{Wprowadzenie}

Coraz większa liczba naukowych zasobów cyfrowych oraz dostępnych w Internecie narzędzi umożliwiających ich przeszukiwanie, które pojawiają się w wyniku rozwoju cyfrowej komunikacji naukowej i cyfrowej humanistyki, skłania do postawienia pytania o zakres ich rzeczywistego wykorzystania (Bomba \& Radomski, 2013; Cisek, 2009). Oba zjawiska budzą zainteresowanie zarówno w sektorze non profit, jak i komercyjnym. Warto zatem zbadać, czy praca i entuzjazm twórców takich źródeł i narzędzi pokrywa się z zainteresowaniem potencjalnych użytkowników, czego podjęła się autorka niniejszego artykułu. Poza naukowcami studenci stanowią ważną grupę odbiorców elektronicznych źródeł i narzędzi naukowych, w dodatku znacznie liczniejszą od grupy pracowników naukowych. Ciekawe wydało się przebadanie, zwłaszcza takiego środowiska studentów, które - jak można się spodziewać - zazwyczaj nie ma styczności z elektronicznymi pomocami naukowymi w ramach realizowanego kierunku studiów, w przeciwieństwie np.do studentów informacji naukowej i bibliotekoznawstwa. Poloniści i historycy stanowią szczególnie ciekawą grupę badawczą, bo z jednej strony źródła i narzędzia cyfrowe adresowane właśnie do nich są bardzo bogate, a z drugiej ich postawy wobec nowych technologii często postrzegane są jako negatywne.

Wskazane powyżej zagadnienie bardzo rzadko było podejmowane przez polskich naukowców. Można tu wskazać tylko badania Małgorzaty Jaskowskiej, Agnieszki Korycińskiej-Huras i Marii Próchnickiej przeprowadzone w 2007 r. na studentach informacji naukowej i bibliotekoznawstwa Uniwersytetu Jagiellońskiego (Jaskowska, Korycińska-Huras \& Próchnicka, 2009a; 2009b). Należy jednak zaznaczyć, że sam temat wykorzystywania naukowych źródeł i narzędzi elektronicznych przez studentów w szerszym kontekście budził większe zainteresowanie (Józefek, 2003; Świgoń, 2008), szczególnie w odniesieniu do zasobów oferowanych przez konkretną instytucję, którą zazwyczaj była biblioteka uczelniana (np. Gabrylewicz \& Słoboda, 2011; Kochan, 2008). Przegląd anglojęzycznego piśmiennictwa naukowego pozwala stwierdzić, że badane zagadnienie było częściej podejmowane, jednak tendencje w stopniu wgłębienia w temat i w poruszanych kontekstach wyglądają analogicznie jak w przypadku polskiej literatury naukowej (np. He, Wu, Yue, Fu, \& Vo, 2012; Tanackovic, Lacovic \& Stanarevic, 2012).

\section{Opis koncepcji i metody przeprowadzonego badania}

\subsection{Cel i zakres tematyczny badania}

Głównym celem badania przedstawionego w niniejszym artykule było poznanie i opisanie zjawiska, jakim jest wykorzystanie źródeł i narzędzi elektronicznych do pisania prac naukowych przez studentów kierunków humanistycznych. Przez źródła elektroniczne rozumiane są tutaj platformy i bazy internetowe, $\mathrm{w}$ których gromadzone, przechowywane i udostępniane są dokumenty o charakterze naukowym, takie jak biblioteki, repozytoria i archiwa cyfrowe oraz bazy pełnotekstowe. Do tej grupy zostały także włączone słowniki językowe oraz encyklopedie. Do narzędzi elektronicznych zaliczone zostały natomiast dostępne w środowisku cyfrowym narzędzia umożliwiające znalezienie i dotarcie do 
dokumentów naukowych oraz baz je udostępniających, czyli przede wszystkim bibliografie elektroniczne, bazy bibliograficzne i bibliograficzno-abstraktowe, wyszukiwarki internetowe ogólne i naukowe, elektroniczne katalogi i multikatalogi bibliotek, a także inwentarze i katalogi archiwaliów. Oprócz nich do narzędzi elektronicznych zostały również zaliczone tzw. menedżery bibliograficzne, tj. programy ułatwiające tworzenie bibliografii zgromadzonych materiałów, generowanie bibliografii załącznikowej i odesłań bibliograficznych w pisanych tekstach.

Z różnego typu prac naukowych zostały wybrane prace magisterskie. Dla większości studentów stanowią one zakończenie i podsumowanie działalności naukowej. Z oczywistych powodów są pisane z większym doświadczeniem niż prace licencjackie. Oprócz tego, warsztat badawczy magistranta jest szerszy i stabilniejszy niż osoby piszącej pracę licencjacką.

Postawione pytania badawcze dotyczyły następujących kwestii: Jakie konkretne źródła i narzędzia były wykorzystywane przez studentów? Skąd dowiedzieli się oni o ich istnieniu? Jak oceniali łatwość korzystania z nich oraz ich przydatność do pisania swoich prac? Czy byli zadowoleni z wyników wyszukiwania przeprowadzonego w źródłach lub za pomocą konkretnych narzędzi? Oprócz tych kwestii ważne okazało się pytanie o przyczyny wykorzystywania wymienionych przez respondentów źródeł i narzędzi. W tym celu konieczne było zbadanie kilku dodatkowych zagadnień, takich jak ogólna znajomość źródeł i narzędzi elektronicznych oraz stosunek do pracy z materiałami cyfrowymi. Sprawdzenie tematów prac magisterskich oraz specyfiki wykorzystywanych w nich rodzajów literatury przedmiotu i podmiotu pozwoliło na stworzenie dla każdego studenta bazy źródeł i narzędzi elektronicznych przydatnych w badaniach respondentów i porównanie tej bazy ze źródłami i narzędziami, z których faktycznie studenci skorzystali.

\subsection{Próba badawcza}

Próbę badawczą stanowili studenci polonistyki i historii Uniwersytetu Warszawskiego w liczbie 14 osób (po 7 osób z każdego kierunku), którzy w momencie przeprowadzania badania byli zaawansowani w zbieraniu materiałów do swoich prac magisterskich. Przy rekrutacji uczestników badania wykorzystano przede wszystkim osobiste kontakty autorki artykułu ze studentami z obu kierunków, ponieważ inne sposoby pozyskania respondentów (takie jak zamieszczanie informacji o badaniu na portalu społecznościowym Facebook czy wysyłanie e-maili za pośrednictwem systemu USOSWeb) okazały się nieskuteczne.

Ważnymi kryteriami doboru były: jednorodne środowisko, z którego wywodzili się respondenci oraz wysoki stopień zaawansowania w zbieraniu materiałów do dysertacji. Pierwsze kryterium umożliwiło przy analizie uzyskanych danych odniesienie ich do jednorodnego kontekstu, na który składały się np. program studiów czy oferta źródeł i narzędzi elektronicznych biblioteki uczelnianej. Zaletą drugiego kryterium było to, że przytaczane opinie i udzielane przez badanych informacje były świeże, co zwiększyło wiarygodność wywiadów. Choć poddana badaniu grupa studentów była nieduża, to generalnie wydaje się, że prezentowała ona preferencje, umiejętności i postawy, które można uznać za charakterystyczne dla środowiska adeptów polonistyki i historii UW.

Grupa badawcza obejmowała studentów drugiego roku dziennych studiów magisterskich. Chociaż studenci obu kierunków mają seminaria dyplomowe już na I roku studiów, to z oczywistych powodów ich prace nad dysertacjami są bardziej zaawansowane 
na roku II. W badaniu uczestniczyło 9 kobiet i 5 mężczyzn. Z powodu małej liczebność grupy badawczej zmienna płci respondentów nie była jednak uwzględniana w analizie wyników.

\subsection{Czynniki mogace mieć wptyw na badanie}

Przy badaniu wykorzystywania źródeł i narzędzi elektronicznych do pisania prac naukowych przez studentów, należało przyjrzeć się kilku barierom, jakie mogli napotkać respondenci i ocenić ich wpływ na badanie. Wśród potencjalnych barier, które - jak się okazało - nie miały negatywnego wpływu na doświadczenia i opinie respondentów, znalazły się: ograniczona obecność takich źródeł i narzędzi w Internecie, które budzą zainteresowanie historyków (opinia wyrażona na podstawie własnych badań autorki); odpłatność za dostęp do nich (zdecydowana większość elektronicznych źródeł i narzędzi wpisuje się w nurt Open Access, a do wielu propozycji komercyjnych studenci mają darmowy dostęp poprzez Bibliotekę Uniwersytecką w Warszawie; ocena stanu rzeczy również na podstawie własnych badań autorki); dostęp do urządzeń podłączonych do Internetu oraz poziom kompetencji informatycznych (Batorowski, 2012). Pewne problemy mogą jednak pojawić się przy poszukiwaniach nowszych polskich monografii, ponieważ ich obecność w bibliotekach czy repozytoriach cyfrowych jest niezadowalająca (Skubała \& Kazan, 2009), co wynika z obowiązującego w Polsce prawa autorskiego oraz postawy polskich naukowców wobec idei Open Access. Lukę w tym segmencie mogą wypełnić strony instytucji naukowych i serwisy wymiany plików, jednak problem stanowi poznanie ich oferty, gdyż są to źródła rozległe, zmienne oraz w przypadku serwisów do wymiany plików - nielegalne.

Poza wymienionymi barierami istotne znaczenie dla badanego zjawiska ma poziom kompetencji informacyjnych studentów, ponieważ wpływa on na wiedzę o cyfrowych źródłach i narzędziach oraz umiejętność ich trafnego wyboru i wykorzystania, a w rezultacie rzutuje na stopień satysfakcji z uzyskanych wyników oraz ocenę samych elektronicznych pomocy naukowych. Niestety, w polskiej literaturze naukowej jest niewiele badań podejmujących ten temat, dlatego trudno jednoznacznie ocenić wpływ poziomu kompetencji informacyjnych na wykorzystywanie źródeł i narzędzi elektronicznych (Jasiewicz, 2012). Z trzech, do których dotarła autorka niniejszego artykułu (Jasiewicz, 2012; Kosmalska, 2013; Mierzecka-Szczepańska, 2013), warto przedstawić raport Studenci-przyszłe kadry polskiej gospodarki, powstały w ramach projektu „Bilans Kapitału Ludzkiego” w 2010 r., ze względu na reprezentatywny charakter badań w nim opisanych. Z raportu wynika, że studenci wysoko oceniają swoje umiejętności korzystania z komputera i Internetu, wyszukiwania i analizy informacji oraz wyciągania na ich podstawie wniosków. Należy jednak dodać, że ze wszystkich kierunków studiów humaniści najniżej ocenili swoje umiejętności (Jasiewicz, 2012).

\subsection{Wybór metody i techniki badawczej oraz zasięg chronologiczny}

Do zbadania poruszanego zagadnienia wybrano podejście jakościowe, ponieważ najlepiej pozwala na dogłębną eksplorację, opisanie i zrozumienie badanego zjawiska. Spośród różnych technik badawczych, biorąc pod uwagę możliwości czasowe i techniczne, zdecydowano się na wywiad częściowo ustrukturyzowany. Taki charakter wywiadu umożliwił 
zarówno poruszenie wszystkich interesujących aspektów zjawiska, jak i zapewnił swobodę toku wywiadu oraz wypowiedzi respondentów. Dzięki takiemu rozwiązaniu badani mogli własnymi słowami opisać swoje doświadczenia, wyrazić opinie, zaś badacz uzyskał możliwość dopytywania, a także rozszerzenia rozmowy o wątki, które nie znalazły się w scenariuszu wywiadu, a okazały się ważne i poznawczo interesujące.

Treść wywiadów po ich przeprowadzeniu została transkrybowana i opracowana za pomocą programu do analizy danych jakościowych Welf QDA. Do analizy zebranego materiału wykorzystano technikę kodowania znaczenia.

Wywiady były przeprowadzane od początku marca do początku maja $2014 \mathrm{r}$.

\section{Wyniki badań}

\subsection{Kontekst badanego zjawiska}

Wśród tematów prac magisterskich polonistów przeważały prace z zakresu literaturoznawstwa. W przypadku historyków najwięcej poruszanych tematów można zaliczyć do historii społecznej. Zdecydowana większość wszystkich tematów odnosiła się do polskiej rzeczywistości, pojedyncze poruszały zagadnienia związane z Ukrainą, Francją i Niemcami, a jeden temat traktował o zjawiskach globalnych. Zasięg czasowy tematów obejmował przeważnie zagadnienia z drugiej połowy XX wieku, mniej zaś z przełomu XVI i XVII wieku, przełomu XIX i XX wieku oraz XXI wieku.

Wykorzystywane źródła miały bardzo różne formy: od literatury pięknej, poezji, reportaży czy prasy (zarówno tej starszej, jak i nowszej) przez archiwalia takie jak korespondencja, pamiętniki, akty urzędowe po filmy, blogi czy portale internetowe. W przypadku archiwaliów należy zaznaczyć, że połowa badanych korzystała z nich w sposób pośredni, np. w postaci zbiorów wydanych lub zdigitalizowanych dokumentów. Wynikało to z podjęcia świadomej decyzji lub braku możliwości dotarcia do potrzebnych materiałów. Wśród form literatury przedmiotu, z których korzystali badani, przeważały monografie. Ponad połowa respondentów oceniła, że stanowią one zdecydowaną większość ich bibliografii. Znacznie rzadziej respondenci wykorzystywali artykuły z czasopism naukowych i prac zbiorowych.

Prawie połowa badanych oceniła, że w niewielkim stopniu używała lub w ogóle nie używała źródeł w postaci cyfrowej. Około jedna trzecia badanych korzystała z wersji elektronicznych materiałów, które stanowiły od 30 do $50 \%$ bibliografii ich prac. Również jedna trzecia całej grupy badawczej oszacowała odsetek używanych źródeł cyfrowych na bardzo wysoki (powyżej 50\%).

W podobnym stopniu studenci wykorzystywali literaturę przedmiotu w postaci cyfrowej. Przeważające oceny ich wykorzystania wahały się w granicach 20-30\%, a 5 badanych stwierdziło, że zgromadziło literaturę przedmiotu tylko w formie papierowej (3 polonistów i 2 historyków).

Trudno jednoznacznie ocenić ogólną znajomość źródeł i narzędzi elektronicznych na podstawie wypowiedzi badanych. Większość wymieniała jedno lub dwa źródła czy narzędzia (6 osób, w tym 4 polonistów i 2 historyków), ale kilka osób nie wymieniło ani jednego (4 badanych, w tym 1 polonista i 3 historyków). Należy jednak zaznaczyć, że choć 
odpowiedź na pytanie o znajomość źródeł i narzędzi bywała negatywna lub uznawano ją za mało satysfakcjonującą, to często badani z obu grup wymieniali takie źródła i narzędzia, gdy dopytywałam ich o tę kwestię po wywiadzie lub podczas wywiadu przy innych pytaniach. Jedną z przyczyn takiej sytuacji może być przyzwyczajenie do wykorzystywanych źródeł i narzędzi, i wyparcie z pamięci tych niewykorzystywanych.

Zdecydowana większość badanych deklaruje, że „nie przepada” za pracą z materiałami w postaci cyfrowej. Tylko dwie osoby (1 polonista i 1 historyk) stwierdziły, że gdyby miały do wyboru taką samą publikację w wersji papierowej i elektronicznej, sięgnęłyby po jej wersję elektroniczną. U studentów można było zaobserwować także pewien dualizm. Popierali ideę dostępu do źródeł i opracowań w postaci cyfrowej, ale równocześnie stwierdzali, że niespecjalnie lubią z nich korzystać. Wśród najczęściej wymienianych powodów niechęci do materiałów elektronicznych wymieniane były trudności z robieniem notatek oraz męczenie wzroku.

Znaczna część badanych ( 9 osób, 4 polonistów i 5 historyków) wspominała, że poszukiwała materiałów do swoich prac, przeglądając bibliografie i przypisy w innych publikacjach (czyli stosowali analizę cytowań i tzw. metodę pomnażania wyników), a część z nich określała ją jako podstawowy sposób szukania literatury podmiotu i przedmiotu. Stosowanie właśnie takiej metody jako głównej wpływa na użycie innych narzędzi do tego przeznaczonych, takich jak chociażby bibliografie czy bazy bibliograficzne.

Tyle samo studentów (5 polonistów i 4 historyków) korzystało także z pomocy innych osób, przede wszystkim promotora, ale także znajomych czy osób specjalizujących się $\mathrm{w}$ temacie ich prac magisterskich.

Z rozmów z połową badanych (3 polonistów i 4 historyków) można było wywnioskować, że z częścią materiałów do swoich prac magisterskich miała do czynienia wcześniej. Studenci wspominali, że niektóre wykorzystywane przez nich źródła poznali podczas studiów lub przy pisaniu prac licencjackich. U części badanych znajomość niektórych źródeł wynikała także z wcześniejszego zainteresowania pewnymi tematami, które z czasem przekształciły się $\mathrm{w}$ przedmiot ich prac magisterskich.

\subsection{Wykorzystywane źródta i narzędzia elektroniczne}

Wszyscy badani wymienili łącznie 58 źródeł i narzędzi, w tym 40 źródeł i 18 narzędzi. Poloniści użyli 17 źródeł i 13 narzędzi, a historycy - 25 źródeł i 9 narzędzi. W tabeli 1, w podziale na typy, przedstawione są źródła elektroniczne wykorzystywane przez badanych.

Wśród najczęściej wykorzystywanych źródeł naukowych największym zainteresowaniem cieszyły się biblioteki cyfrowe. Biorąc pod uwagę tematy poruszane w pracach magisterskich, należy stwierdzić, że z bibliotek cyfrowych skorzystały osoby, które mogły w nich znaleźć interesujący materiał (było to 4 polonistów ${ }^{2}$ i 6 historyków). Zdecydowana większość badanych szukała w nich źródeł. Dwóch studentów znalazło w nich

2 W tabeli umieszczono dane uzyskane od 3 polonistów, choć w badaniach uczestniczyło ich 4 . Nie mogły jednak zostać uwzględnione informacje otrzymane od jednej osoby, bo wspomniała ona wprawdzie, że korzystała z Federacji Bibliotek Cyfrowych, lecz nie określiła wyraźnie, do których konkretnie bibliotek ostatecznie trafiła za pośrednictwem multikatalogu. 
literaturę przedmiotu, jednak w przypadku pierwszej osoby były to materiały z 20-lecia międzywojennego, a w przypadku drugiej - opracowania ukraińskie udostępniane na niepolskich stronach WWW. Badani w sumie wymienili 13 bibliotek cyfrowych ${ }^{3}$, w tym 3 zagraniczne (Historic Cities, Litopys oraz Electronic Library of Ukrainian Literature). Należy zauważyć, że zagraniczne biblioteki cyfrowe dla korzystających z nich osób odegrały kluczową rolę w dotarciu do źródeł niezbędnych do przygotowania prac magisterskich. Bez nich studenci ci albo musieliby włożyć znacznie więcej czasu i energii w dotarcie do nich, albo by do nich nie dotarli i w rezultacie dysertacje na dany temat mogłyby w ogóle nie powstać.

Tabela 1. Wykorzystywane źródła ze względu na typ

\begin{tabular}{|l|c|c|c|}
\hline \multirow{2}{*}{ Typ i nazwa źródła } & \multicolumn{2}{c|}{ Liczba osób korzystających } \\
\cline { 2 - 4 } & z polonistyki & z historii & razem \\
\hline $\begin{array}{l}\text { Biblioteki cyfrowe } \\
\text { w tym: }\end{array}$ & 3 & 5 & 9 \\
\hline Wolne Lektury & 1 & - & 1 \\
\hline Polska Biblioteka Internetowa & 1 & - & 1 \\
\hline Biblioteka Cyfrowa BUW & - & 1 & 1 \\
\hline Mazowiecka Biblioteka Cyfrowa & - & 2 & 2 \\
\hline Wielkopolska Biblioteka Cyfrowa & - & 1 & 1 \\
\hline Pomorska Biblioteka Cyfrowa & - & 1 & 1 \\
\hline $\begin{array}{l}\text { Cyfrowa Biblioteka Druków Ulotnych Polskich i Polski } \\
\text { Dotyczących }\end{array}$ & - & 1 & 1 \\
\hline $\begin{array}{l}\text { Kolekcja Starych Druków Biblioteki Instytutu } \\
\text { Historycznego UW }\end{array}$ & - & 1 & 1 \\
\hline Historic Cities & - & 1 & 1 \\
\hline Śląska Biblioteka Cyfrowa & - & 1 & 1 \\
\hline Litopys & - & 1 & 1 \\
\hline Electronic Library of Ukrainian Literature & - & 1 & 1 \\
\hline Google Books & - & 1 & 1 \\
\hline $\begin{array}{l}\text { Repozytoria } \\
\text { w tym: }\end{array}$ & - & 1 & $\mathbf{1}$ \\
\hline AMUR & - & 1 & 1 \\
\hline RUMAK & - & 1 & 1 \\
\hline $\begin{array}{l}\text { Archiwum Historii Mówionej Muzeum Powstania } \\
\text { Warszawskiego }\end{array}$ & - & & 3 \\
\hline JSTOR & - & & 1 \\
\hline
\end{tabular}

\footnotetext{
${ }^{3}$ De facto było ich więcej z powodu opisanego w przypisie 1.
} 


\begin{tabular}{|c|c|c|c|}
\hline 1 & 2 & 3 & 4 \\
\hline $\begin{array}{l}\text { Słowniki } \\
\text { w tym: }\end{array}$ & 1 & 1 & 2 \\
\hline Słownik języka polskiego PWN & 1 & - & 1 \\
\hline Słownik wileński & 1 & - & 1 \\
\hline Słownik staroruski & - & 1 & 1 \\
\hline Synonimy.pl & 1 & - & 1 \\
\hline Narodowy Korpus Języka Polskiego & 1 & - & 1 \\
\hline $\begin{array}{l}\text { Encyklopedie } \\
\text { w tym: }\end{array}$ & 1 & 1 & 2 \\
\hline Wikipedia & 1 & - & 1 \\
\hline Internet Encyclopedia of Ukraine & - & 1 & 1 \\
\hline $\begin{array}{l}\text { Portale i strony internetowe } \\
\text { w tym: }\end{array}$ & 5 & 3 & 8 \\
\hline Chomikuj.pl & 2 & 2 & 4 \\
\hline sylabusy zajęć na UW & 2 & - & 2 \\
\hline portale internetowe tygodników opiniotwórczych & 1 & - & 1 \\
\hline portale internetowe gazet branżowych & 1 & - & 1 \\
\hline internetowe wydania gazet & 1 & - & 1 \\
\hline portale z poezją & 1 & - & 1 \\
\hline portale informacyjne (np. Onet) & 1 & - & 1 \\
\hline portal Filmweb & 1 & - & 1 \\
\hline portale $\mathrm{z}$ filmami online & 1 & - & 1 \\
\hline portal Sejm Wielki & 1 & - & 1 \\
\hline Wrzuta & - & 1 & 1 \\
\hline YouTube & - & 1 & 1 \\
\hline portal konkretnego naukowca & - & 1 & 1 \\
\hline Film Polski & - & 1 & 1 \\
\hline filmowe strony fanowskie & - & 1 & 1 \\
\hline fora internetowe & - & 1 & 1 \\
\hline
\end{tabular}

Zdecydowanie rzadziej badani sięgali do pozostałych typów źródeł. Mając na uwadze poruszane przez studentów tematy dysertacji, należy jednak zaznaczyć, że włączenie do poszukiwań tylko repozytoriów i baz pełnotekstowych z cyfrowymi czasopismami oraz książkami mogłoby przynieść satysfakcjonujące rezultaty poszukiwań literatury przedmiotu. Warto w tym miejscu wspomnieć o dwóch badanych, którzy zamierzali korzystać z książek anglojęzycznych, jednak nie wiedzieli, jak łatwo je pozyskać, a w ich przypadku bardzo pomocna okazałaby się baza ebrary, do której BUW wykupuje dostęp. Poza tym, ciekawe opinie udało się zebrać o bazie JSTOR. Dwoje historyków wyraziło zdanie, że właśnie ta baza może okazać się najbardziej dla nich przydatna, o czym świadczy następująca wypowiedź: 
Badacz: Jak dotarłaś do JSTOR-a?

Student: Ktoś na pierwszym roku nam powiedział, że coś takiego jest? Takie mam wrażenie. A wiem, mamy cudowne zajęcia „Wstęp do badań historycznych” (...) Od tej pory to jest magiczne źródło, gdzie wszyscy wszystko znajdują, w sensie baza, gdzie wszyscy wszystko znajdują. Do wszystkich prac. Przez 5 lat studiów nigdy mnie nie zawiódł (H6).

Ciekawy komentarz można odnieść do encyklopedii Wikipedia. Z wywiadów wynika, że studenci traktowali ją jako doraźną, szybką pomoc przy pracy nad literaturą podmiotu, a nie jako główne źródło informacji. Oprócz tego, w przypadku jednej osoby pojawiła się ona mimochodem w kontekście wyszukiwarki Google. Biorąc pod uwagę wypowiedzi wspomnianych studentów można pokusić się o hipotezę, że z Wikipedii korzystało jednak więcej osób. Być może nie wspomniały o niej, gdyż używały jej właśnie tylko jako doraźną pomoc, a nie wartościową literaturę przedmiotu, w dodatku zazwyczaj za pośrednictwem wyszukiwarki Google.

Na uwagę zasługują także portale i strony internetowe, które dostarczały uczestnikom wywiadów zarówno materiał źródłowy (np. portale informacyjne, YouTube), jak i literaturę przedmiotu (np. sylabusy zajęć na UW, portale naukowców). Materiały pobrane z serwisu do wymiany plików Chomikuj.pl były przede wszystkim filmami, literaturą piękną, ale także opracowaniami naukowymi i źródłami.

W tabeli 2 zaprezentowano listę narzędzi użytych przez uczestników badania do poszukiwań źródeł i opracowań, zorganizowaną również ze względu na ich typ.

Wśród wymienionych narzędzi największą popularnością cieszyły się: wyszukiwarka internetowa Google oraz internetowe katalogi polskich bibliotek naukowych, którym warto przyjrzeć się bliżej.

W przypadku wyszukiwarki Google należy zwrócić uwagę na problemy związane ze wskazaniem źródła wiedzy o niej, co wiąże się z jej prawie 16-letnią obecnością w Internecie oraz pokazuje, jak bardzo ta wyszukiwarka wrosła w życie studentów i stała się jego stałym elementem. Poniżej zaprezentowano kilka typowych wypowiedzi respondentów:

Skąd znam? [śmiech] Wszyscy to znają [śmiech]. Nie no, skąd to trudno mi powiedzieć, po prostu się zaczęło używać i tyle (P5).

Google? [śmiech] Jeju, nie wiem, skąd ją znam [śmiech]. Po prostu, jest wiodąca, jest narzucająca się (H5).

Uczestnicy wywiadów używali jej przede wszystkim jako szybką pomoc przy weryfikacji czy uzupełnianiu informacji, do wstępnego rozeznania badanego tematu oraz do wyszukiwania konkretnych publikacji w postaci cyfrowej, gdy nie udało się dotrzeć do ich wersji papierowej. W ich oczach nie znalazła ona natomiast uznania jako podstawowe narzędzie do poszukiwań literatury przedmiotu.

Także pytanie o źródło wiedzy o katalogu internetowym BUW-u okazało się dla uczestników badania wyzwaniem. Studenci najczęściej wspominali zajęcia przeprowadzone $\mathrm{w}$ bibliotece, organizowane dla nich jeszcze w liceum, oraz własne poszukiwania. Rzadko natomiast wymieniali szkolenie biblioteczne realizowane przez BUW, które jest obowiązkowe dla wszystkich studentów UW na I roku studiów.

Studenci przede wszystkim używali katalogu BUW do wyszukiwania konkretnych publikacji. Problemy pojawiały się przy korzystaniu z haseł przedmiotowych. Ci, którzy zdecydowali się na taką metodę poszukiwań zazwyczaj oceniali ją jako mało pomocną (tylko 2 osoby były z niej zadowolone). Część, mając w pamięci wcześniejsze negatywne doświadczenia, nawet jej nie próbowała. Z wypowiedzi badanych można wywnioskować, 
że trudność sprawia im stworzenie odpowiedniej instrukcji wyszukiwawczej, a także, że nie znają wszystkich opcji wyszukiwania dostępnych w OPAC BUW-u, bowiem niektórzy z nich hasła przedmiotowe wpisywali w pole „tytuł”.

Tabela 2. Wykorzystane narzędzia według typów

\begin{tabular}{|c|c|c|c|}
\hline \multirow{2}{*}{ Typ i nazwa narzędzia } & \multicolumn{3}{|c|}{ Liczba osób korzystających } \\
\hline & z polonistyki & $\mathrm{z}$ historii & razem \\
\hline $\begin{array}{l}\text { Bibliografie } \\
\text { w tym: }\end{array}$ & 2 & 1 & 3 \\
\hline Polska Bibliografia Literacka & 2 & - & 2 \\
\hline Bibliografia Estreichera & - & 1 & 1 \\
\hline Bibliografia Zawartości Czasopism & 1 & - & 1 \\
\hline Google & 7 & 7 & 14 \\
\hline Google Scholar & - & 2 & 2 \\
\hline $\begin{array}{l}\text { Katalogi polskich bibliotek naukowych } \\
\text { w tym: }\end{array}$ & 7 & 7 & 14 \\
\hline katalog BUW & 6 & 7 & 13 \\
\hline katalog BN & 4 & 6 & 10 \\
\hline $\begin{array}{l}\text { katalog biblioteki im. Wacława Borowego (Wydział Polo- } \\
\text { nistyki UW) }\end{array}$ & 2 & - & 2 \\
\hline $\begin{array}{l}\text { Katalogi bibliotek uniwersyteckich zagranicznych } \\
\text { w tym: }\end{array}$ & 1 & 1 & 2 \\
\hline katalog biblioteki Uniwersytetu w Tybindze & 1 & - & 1 \\
\hline katalog centralny bibliotek Uniwersytetu Oxfordzkiego & - & 1 & 1 \\
\hline $\begin{array}{l}\text { Katalogi warszawskich bibliotek publicznych } \\
\text { w tym: }\end{array}$ & 3 & - & 3 \\
\hline katalog Biblioteki Publicznej m.st. Warszawy - baza & 2 & - & 2 \\
\hline $\begin{array}{l}\text { katalog Biblioteki Publicznej m.st. Warszawy - zdigitalizo- } \\
\text { wany kartkowy }\end{array}$ & 1 & - & 1 \\
\hline katalog Biblioteki Publicznej w dzielnicy Żoliborz & 1 & - & 1 \\
\hline katalog Biblioteki Publicznej w dzielnicy Śródmieście & 2 & - & 2 \\
\hline katalog Biblioteki Publicznej w dzielnicy Praga Południe & 1 & - & 1 \\
\hline Federacja Bibliotek Cyfrowych & 2 & - & 2 \\
\hline Zotero & - & 1 & 1 \\
\hline $\begin{array}{l}\text { Księgarnie internetowe } \\
\text { w tym: }\end{array}$ & 1 & 2 & 2 \\
\hline Amazon & - & 1 & 1 \\
\hline Główna Księgarnia Naukowa im. Bolesława Prusa & - & 1 & 1 \\
\hline
\end{tabular}


Choć aż 10 respondentów korzystało z katalogu BN, to jednak liczba wyszukiwań jakie w nim przeprowadzili była raczej mała. Badani rzadko do niego zaglądali, nie traktowali go jako wiodącego narzędzia do zbierania materiałów do dysertacji, czego przyczyn należy upatrywać w negatywnym stosunku do biblioteki, który często ujawniał się w wypowiedziach studentów, a nie w samym katalogu.

Pozostałe narzędzia, takie jak bibliografie, bazy bibliograficzne i bibliograficzno-abstraktowe, wyszukiwarki naukowe czy menedżery bibliograficzne zdecydowanie rzadziej były wykorzystywane lub nie sięgano do nich wcale. Biorąc pod uwagę tematy dysertacji respondentów, prawie każde z tych narzędzi mogłoby okazać się przydatne przy poszukiwaniach materiałów do przygotowywanych prac, trudno jednak oszacować, w jakim stopniu. Przyczyn takiej sytuacji należy upatrywać przede wszystkim w niewielkiej wiedzy studentów o istnieniu takich narzędzi, niesatysfakcjonującego zbioru monografii dostępnych w Internecie, dość powszechnego zwyczaju szukania materiałów za pomocą techniki pomnażania wyników przede wszystkim na podstawie bibliografii załącznikowych w publikacjach papierowych oraz ogólnego przywiązania do środowiska papierowego, widocznego u studentów obu kierunków.

\subsection{Skąd studenci czerpia wiedze o wykorzystywanych źródtach i narzędziach elektronicznych?}

Uczestnicy badania poznawali opisywane źródła i narzędzia cyfrowe w bardzo różnych okolicznościach i na bardzo różne sposoby. Analiza wypowiedzi na ten temat pozwala na wyróżnienie dwóch kategorii, do których można przypisać najwięcej odpowiedzi. Pierwsza to własne poszukiwania. Drugą stanowią zajęcia prowadzone na studiach. Studenci wymieniali bardzo różne przedmioty, zarówno związane z obraną specjalizacją w ramach kierunku studiów, jak i obowiązkowe dla wszystkich studentów. Informacje na temat źródeł i narzędzi były przekazywane w sposób zorganizowany (np.jako oddzielna jednostka lekcyjna) lub niezorganizowany (np. wspomniane mimochodem na wykładzie lub w formie zalecenia przez promotora).

Zdecydowanie mniejszą rolę w poznawaniu źródeł i narzędzi naukowych odegrali znajomi badanych studentów. Ciekawe, że kilka osób wspomniało tu o zajęciach prowadzonych już na etapie edukacji ponadgimnazjalnej.

Biorąc pod uwagę kierunek studiów, należy zauważyć, że poloniści najczęściej zdobywali wiedzę o źródłach i narzędziach sami, zaś historycy równie często podczas zajęć uniwersyteckich, jak i sami.

\subsection{Przydatność źródet i narzędzi elektronicznych oraz ocena wyników uzyskane dzięki ich wykorzystywaniu}

Praktycznie każde wykorzystane źródło lub narzędzie elektroniczne okazało się przydatne przy poszukiwaniach materiałów do prac magisterskich. Badani studenci byli z nich zadowoleni, aczkolwiek w różnym stopniu. Zazwyczaj oceniali je pozytywnie lub umiarkowanie pozytywnie. Największe emocje wzbudziły katalogi BUW i Biblioteki Narodowej. Z opinii części studentów wynika, że są trudne w obsłudze i mało intuicyjne. Oprócz tego, studenci oczekują od nich, by przy mało precyzyjnych instrukcjach wyszukiwawczych dawały bardzo 
precyzyjne wyniki. Przyczyn takiej oceny nie należy szukać tylko w wadach technicznych tych narzędzi, ale także w poziomie kompetencji informacyjnych badanych czy edukacji informacyjnej. Można postawić także hipotezę, że istotny wpływ na oceny respondentów może wywierać wyszukiwarka Google, która przyzwyczaiła swoich użytkowników do pewnych zachowań (jak np. wpisywania zapytania informacyjnego w okienko do ogólnych poszukiwań bez ustawiania filtrów) i wysokiego poziomu skuteczności, której oczekują oni także od innych narzędzi wyszukiwawczych. Potwierdzenie hipotezy szczegółowymi badaniami stanowiłoby istotną informację dla twórców systemów bibliotecznych i zapewne wywarłoby wpływ na kształt tych narzędzi.

Studenci bardzo rzadko komentowali cechy techniczne używanych źródeł i narzędzi. Częściej koncentrowali się na ich zawartości. Warto dodać, że w wielu przypadkach niesatysfakcjonujące poszukiwania nie wpływały negatywnie na ocenę źródła czy narzędzia, co można wytłumaczyć małymi oczekiwaniami badanych. Często bowiem wspominali, że badane przez nich zagadnienia są słabo opracowane i trudno cokolwiek znaleźć na ich temat. Oprócz tego, dla studentów ważny był szybki dostęp do źródeł i narzędzi, nieograniczony czasem ani miejscem.

\section{Wnioski}

Analiza przeprowadzonych wywiadów pozwoliła stworzyć szczegółowy i spójny obraz zjawiska wykorzystywania źródeł i narzędzi elektronicznych przez studentów do pisania prac magisterskich oraz wysnuć kilka istotnych wniosków.

Uczestnicy badania najczęściej włączali elektroniczne źródła do swych poszukiwań w momencie, gdy nie byli w stanie dotrzeć do interesujących materiałów w formie analogowej. Ponieważ trudniej skorzystać z oryginalnych materiałów źródłowych umieszczonych w archiwach czy magazynach bibliotecznych niż z drukowanych monografii i czasopism naukowych, wśród najczęściej wykorzystywanych źródeł elektronicznych znalazły się biblioteki cyfrowe gromadzące właśnie cyfrowe kopie takiego rodzaju zasobów. Jeżeli studenci korzystali z innego typu elektronicznych źródeł, to przede wszystkim w celu uzupełnienia zebranych materiałów, w końcowej, a nie głównej fazie poszukiwań literatury przedmiotu. Przy szukaniu przyczyn małej popularności źródeł elektronicznych, zawierających opracowania, należy brać także pod uwagę ich niesatysfakcjonującą obecność w Internecie, choć ten czynnik wydaje się być mniej istotny. Wśród najczęściej wykorzystywanych narzędzi znalazły się takie, które umożliwiają dotarcie do materiałów w formie tradycyjnej, czyli były to przede wszystkim katalogi elektroniczne bibliotek. Oprócz tego, dużym powodzeniem cieszyła się wyszukiwarka Google. Studenci rzadko sięgali po pomoce o charakterze bibliograficznym oraz wyszukiwarki naukowe. Poza tym, wykazali niewielką znajomość menedżerów bibliograficznych.

Sprawdziła się opinia na temat konserwatywnego podejścia polonistów i historyków do pracy w środowisku cyfrowym. Ich postawa nie odnosi się tylko do korzystania z publikacji w formie elektronicznej, ale także katalogów bibliotek oraz sposobu wyszukiwania materiałów naukowych.

Pozycja publikacji elektronicznych w opiniach badanej grupy studentów nie jest zbyt silna, co znajduje potwierdzenie $w$ innych badaniach na temat korzystania $\mathrm{z}$ materiałów w postaci cyfrowej. Nadal istotną przeszkodę stanowią uwarunkowania sprzętowe 
(dyskomfort czytania z ekranu komputera) oraz przyzwyczajenia respondentów. Być może upowszechnienie czytników książek elektronicznych wpłynęłoby na zwiększenie użytkowania źródeł elektronicznych.

Studenci sięgali po cyfrowe pomoce do pisania prac magisterskich, jednak nie wykorzystywali w pełni ich bogatego zasobu. Należy to tłumaczyć zarówno przyzwyczajeniami uczestników badania, jak i ich poziomem wiedzy na temat elektronicznych źródeł i narzędzi.

Także stopień objęcia respondentów edukacją z zakresu kompetencji informacyjnych wydaje się być niesatysfakcjonujący, szczególnie w przypadku polonistów. Porównanie wypowiedzi studentów obu kierunków pokazało, że historycy częściej dowiadywali się na zajęciach o elektronicznych źródłach i narzędziach niż poloniści, co więcej, częściej korzystali z cyfrowych pomocy, które można określić jako stricte naukowe (np. repozytoria czy wyszukiwarki naukowe), aczkolwiek stopień ich wykorzystania mógłby być jeszcze większy.

Wątpliwości budzi także poziom kompetencji informacyjnych respondentów. Aby je potwierdzić bądź rozwiać należałoby przeprowadzić szczegółowe badania. Na podstawie wywiadów można tylko zasygnalizować problemy studentów związane z tworzeniem instrukcji wyszukiwawczych, operowaniem hasłami przedmiotowymi w elektronicznych katalogach bibliotek oraz wykorzystywaniem zaawansowanych opcji wyszukiwania w elektronicznych źródłach i narzędziach. Wysoki poziom kompetencji informacyjnych mógłby przyczynić się do zwiększenia satysfakcji z wyników wyszukiwań oraz samego użytkowania elektronicznych pomocy.

Nawet wysokie kompetencje informacyjne nie wypełnią jednak braków w dostępnych cyfrowo zasobach literatury naukowej. Badani często w wywiadach podkreślali, że tematy ich dysertacji nie budzą zbyt dużego zainteresowania środowiska naukowego. Oprócz tego, z wypowiedzi magistrantów wynika, że jeśli znaleźli interesujące materiały, to zazwyczaj były one w wersji tradycyjnej, co wskazuje na ubogą ofertę opracowań, szczególnie monografii dostępnych w Internecie w postaci cyfrowej. Jednak mając na uwadze postawy przedstawicieli obu kierunków studiów reprezentowanych w próbie badawczej wobec pracy w środowisku cyfrowym, za uzasadnioną należy uznać wątpliwość, czy istotnie korzystaliby z elektronicznych wersji opracowań monograficznych, nawet gdyby ich zasób w sieci był zadowalający.

Przeprowadzone badanie miało charakter jakościowej analizy kontekstowej, w której pozyskane od uczestników badania dane i opinie konfrontowane były z rozpoznanym wcześniej stanem rzeczy w zakresie możliwości korzystania przez studentów z elektronicznych źródeł i narzędzi naukowych. Ze względu na ograniczoną liczebność grupy badawczej, uzyskanych wyników nie można odnieść do całej populacji studentów, a nawet populacji polonistów i historyków, pokazują one jednak ciekawe tendencje i zjawiska, którym warto przyjrzeć się bliżej, również w odniesieniu do innych środowisk naukowych.

\section{Bibliografia}

Batorowski, D. (2012). Korzystanie z technologii informacyjno-komunikacyjnych. W: J. Czapiński \& T. Panek (red.), Diagnoza społeczna 2011: warunki i jakość życia Polaków: raport [online]. Warszawa: Rada Monitoringu Społecznego, 299-327, [22.08.2014], http://www.diagnoza.com/ pliki/raporty/Diagnoza_raport_2011.pdf

Bomba, R.; Radomski, A. (red.). (2013). Zwrot cyfrowy w humanistyce [online]. Lublin: e-naukowiec, [22.08.2014], https://depot.ceon.pl//handle/123456789/2062 
Cisek, S. (2009). Nauka 2.0: nowe narzędzia komunikacji naukowej [online]. Informacja w świecie cyfrowym. Biblioteka Główna Wyższej Szkoły Biznesu w Dąbrowie Górniczej im. J. Altkorna [22.08.2014], http://informacjacyfrowa.wsb.edu.pl/pdfs/nauka 2.0.pdf

Gabrylewicz, N.; \& Słoboda, K. (2011). Wykorzystanie elektronicznych źródet informacji przez studentów Politechniki Lubelskiej [online]. eLIS [28.08.2014], http://eprints.rclis.org/15726/1/K.\%20 S\%C5\%82oboda\%2C\%20N.\%20Gabrylewicz\%20Wykorzystanie\%20elektronicznych...\%20MS\%20 Word\%202007.pdf

He, D.; Wu, D.; Yue, Z.; Fu, A.; Vo, K. T. (2012). Undergraduate students' interaction with online information resources in their academic tasks: A comparative study. Aslib Proceedings, 64(6), 615-640.

Jasiewicz, J. (2012). Analiza SWOT poziomu kompetencji informacyjnych i medialnych polskiego społeczeństwa w oparciu o istniejące badania społeczne [online]. W: J. Lipszyc (red.), Cyfrowa przyszłość: edukacja medialna i informacyjna w Polsce - raport otwarcia. Warszawa: Fundacja Nowoczesna Polska, 21-68, [22.08.2014], http://nowoczesnapolska.org.pl/wp-content/uploads/2012/01/Raport-Cyfrowa-Przyszłość-.pdf

Jaskowska, M., Korycińska-Huras, A. \& Próchnicka, M. (2009a). Bibliografia jako źródło informacji naukowej - w opinii studentów. W: J. Woźniak-Kasperek \& M. Ochmański (red.), Bibliografia: teoria, praktyka, dydaktyka. Warszawa: Wydaw. SBP, 233-258.

Jaskowska, M., Korycińska-Huras, A. \& Próchnicka, M. (2009b). Zachowania informacyjne autorów prac licencjackich z zakresu informacji naukowej i bibliotekoznawstwa. Tendencje w wykorzystaniu źródeł elektronicznych i drukowanych. W: K. Migoń \& M. Skalska-Zlat (red.), Uniwersum piśmiennictwa wobec komunikacji elektronicznej. Wrocław: Wydaw. Uniwersytetu Wrocławskiego, 292-311.

Józefek, L. (2003). Wykorzystywanie elektronicznych źródeł informacji przez studentów różnych kierunków. W: E. Solarczyk-Ambrozik \& A. Zduniak (red.), Edukacyjne wyzwania i zagrożenia poczqtku XXI wieku. Warszawa: Katedra Nauk Humanistycznych Wyższej Szkoły Oficerskiej Wojsk Lądowych, 251-256.

Kosmalska, M. (2013). Kompetencje informacyjne - próba analizy ich poziomu wsród użytkowników Biblioteki Wydziału Prawa i Administracji Uniwersytetu Szczecińskiego. W: D. Ziarkowski (red.), Rola ośrodków informacji naukowej bibliotek naukowych w nabywaniu i kształtowaniu umiejętności informacyjnych. Szczecin: Biblioteka Główna Uniwersytetu Szczecińskiego, 34-43.

Mierzecka-Szczepańska, A. (2013). Badania zachowań informacyjnych. Warszawa: Wydaw. SBP.

Skubała, E. \& Kazan, A. (2009). Dobór publikacji w polityce zarządzania biblioteką cyfrową. Analiza wykorzystania zasobów bibliotek cyfrowych wspólnie przeszukiwanych w ramach FBC. W: C. Mazurek, M. Stroiński \& J. Węglarz (red.), Polskie biblioteki cyfrowe 2008: materiaty z konferencji zorganizowanej w dniach 24-25 listopada 2008 roku przez: Bibliotekę Kórnicka PAN, Poznańska Fundację Bibliotek Naukowych, Poznańskie Centrum Superkomputerowo-sieciowe. Poznań: Ośrodek Wydawnictw Naukowych, 63-72.

Spaleniak, A. \& Olszewska, H. (2008). E czy print - co wybierają czytelnicy Biblioteki Uniwersyteckiej w Poznaniu. W: R. Gaziński (red.), Dokąd zmierzamy? Książa i jej czytelnik: materiały z II Ogólnopolskiej Konferencji Naukowej zorganizowanej przez Bibliotekę Głównq Uniwersytetu Szczecińskiego, Międzyzdroje, 20-22 września 2007 roku. Szczecin: Biblioteka Główna Uniwersytetu Szczecińskiego, 255-262).

Świgoń, M. (2008). Znaczenie i dostępność źródeł informacji w opinii studentów - wyniki badań. Praktyka i Teoria Informacji Naukowej i Technicznej, 2, 22-30.

Tanackovic, S. F., Lacovic, D. \& Stanarević, S. (2012). LIS students seeking information for their final papers: small-scale study at the Faculty of Philosophy in Osijek [online]. In: F. Pehar (ed.), Libraries in the Digital Age (LIDA) Proceedings, Vol. 12. Zadar: University of Zadar, Department of Information Sciences [22.08.2014], http://ozk.unizd.hr/proceedings/index.php/lida2012/article/ view $/ 10$ 


\title{
Using electronic resources and tools by Polish students of the humanities
}

\begin{abstract}
Purpose/thesis: The purpose of this paper is to present the results of the research concerning the information behaviour of students of humanities at the University of Warsaw. It is connected with the usage of scientific resources and electronic tools for preparing master's theses on the basis of one's own research.

Approach/methods: In the research a qualitative approach was applied using the technique of partially structured interview. The research group included 14 students: 7 graduates of Polish philology and 7 graduates of history who were second years students of MA Studies in the academic year 2013/2014. Results and conclusions: The analysis of the collected information indicated that the respondents tended to employ electronic resources when the access to the materials in the traditional form was difficult, whereas electronic tools were used for searching specific publications in a paper or electronic version. The most popular tools turned out to be digital libraries, Google Web Search and electronic libraries catalogues. Despite the fact that students were generally open to digital technologies and supported the development of scientific resources of Open Access, it has been proven that their knowledge of such tools as reference managers was in fact poor. They seldom used this tool while writing their master's theses. As a result the general belief saying that humanists prefer to work in a paper environment was confirmed.

Originality/value: The research conducted fills the gap in studies on students' information behaviour. Its particular value is the selection of the research group among the students of humanities, who so far seldom have been included in this type of research.
\end{abstract}

\section{Keywords}

Scientific electronic resource. Scientific electronic tool. User behaviour. Information literacy. User education. Digital humanities.

ANNA KAMIŃSKA jest doktorantką w Instytucie Informacji Naukowej i Studiów Bibliologicznych Uniwersytetu Warszawskiego. Napisała pracę magisterska pt. Wykorzystanie źródet i narzędzi elektronicznych przez studentów przy pisaniu prac naukowych na przykładzie magistrantów polonistyki i historii Uniwersytetu Warszawskiego, obroniona w lipcu 2014 roku na Uniwersytecie Warszawskim. Jej zainteresowania naukowe to: cyfrowa komunikacja naukowa oraz zachowania informacyjne.

Kontakt $z$ autorem:

a.t.kaminska@gmail.com

Instytut Informacji Naukowej i Studiów Bibliologicznych

Uniwersytetu Warszawskiego

ul. Nowy Świat 69, III piętro, p. 310A

00-927 Warszawa 